\title{
Naturally driven variability in the global secondary organic aerosol over a decade
}

\author{
K. Tsigaridis ${ }^{1}$, J. Lathière ${ }^{2}$, M. Kanakidou ${ }^{1}$, and D. A. Hauglustaine ${ }^{2}$ \\ ${ }^{1}$ Environmental Chemical Processes Laboratory, Department of Chemistry, University of Crete, POBox 1470, 71409 \\ Heraklion, Greece \\ ${ }^{2}$ LSCE, CNRS/CEA, l'Orme-des-Merisiers, 91191 Gif-sur-Yvette, France
}

Received: 23 December 2004 - Published in Atmos. Chem. Phys. Discuss.: 9 March 2005

Revised: 11 May 2005 - Accepted: 25 June 2005 - Published: 26 July 2005

\begin{abstract}
In order to investigate the variability of the secondary organic aerosol (SOA) distributions and budget and provide a measure for the robustness of the conclusions on human induced changes of SOA, a global 3-dimensional chemistry transport model describing both the gas and the particulate phase chemistry of the troposphere has been applied. The response of the global budget of SOA to temperature and moisture changes as well as to biogenic emission changes over a decade (1984-1993) has been evaluated. The considered emissions of biogenic non-methane volatile organic compounds (VOC) are driven by temperature, light and vegetation. They vary between 756 and $810 \mathrm{TgCy}^{-1}$ and are therefore about 5.5 times higher than the anthropogenic VOC emissions. All secondary aerosols (sulphuric, nitrates and organics) are computed on-line together with the aerosol associated water. Over the studied decade, the computed natural variations $(8 \%)$ in the chemical SOA production from biogenic VOC oxidation equal the chemical SOA production from anthropogenic VOC oxidation. Maximum values are calculated for 1990 (warmer and drier) and minimum values for 1986 (colder and wetter). The SOA computed variability results from a $7 \%$ increase in biogenic VOC emissions from 1986 to 1990 combined with $8.5 \%$ and 6\% increases in the wet and dry deposition of SOA and leads to about $11.5 \%$ increase in the SOA burden of biogenic origin. The present study also demonstrates the importance of the hydrological cycle in determining the built up and fate of SOA in the atmosphere. It also reveals the existence of significant positive and negative feedback mechanisms in the atmosphere responsible for the non linear relationship between emissions of biogenic VOC and SOA burden.
\end{abstract}

Correspondence to: M. Kanakidou

(mariak@chemistry.uoc.gr)

\section{Introduction}

Aerosols exert various impacts on the earth system affecting climate, atmospheric chemistry, nutrients cycling, visibility and human health. An important fraction of aerosol that is only recently considered in global model simulations is the secondary organic aerosol (SOA) (Kanakidou et al., 2000, 2005; Chung and Seinfeld, 2002; Tsigaridis and Kanakidou, 2003). All global modeling studies agree that a major precursor of SOA is biogenics (Griffin et al., 1999; Kanakidou et al., 2000; Chung and Seinfeld, 2002; Tsigaridis and Kanakidou, 2003; Derwent et al., 2003; Bonn et al., 2003; Lack et al., 2004). Emissions from the terrestrial biosphere are affected by meteorological conditions like sunlight, temperature, moisture etc (Guenther et al., 1995; Naik et al., 2004). Earth's climate and atmospheric circulation are known to be subject to large natural variability that also reflects to the atmospheric composition as demonstrated by ice core measurements (Falkowski et al., 2000). A critical step in understanding the behavior of trace constituents in the atmosphere is the evaluation of the importance of the human induced changes that presupposes the understanding and evaluation of the natural variability (see discussion on $\mathrm{CO}_{2}$ in Falkowski et al., 2000). In particular, for SOA although the anthropogenic emissions enhance both ozone and preexisting aerosols (Tsigaridis and Kanakidou, 2003), the natural variability of biogenic VOC emissions could affect SOA levels as much as the anthropogenic emissions. The variability of SOA levels in the atmosphere exerts in turn, together with the other aerosol components, an impact on radiation and on the hydrological cycle (Kanakidou et al., 2005 and references therein). Thus, SOA might be involved in significant chemistry/climate feedbacks that enhance stability or perturbation of the atmosphere and climate, and that deserve careful investigation (Kulmala et al., 2004). 

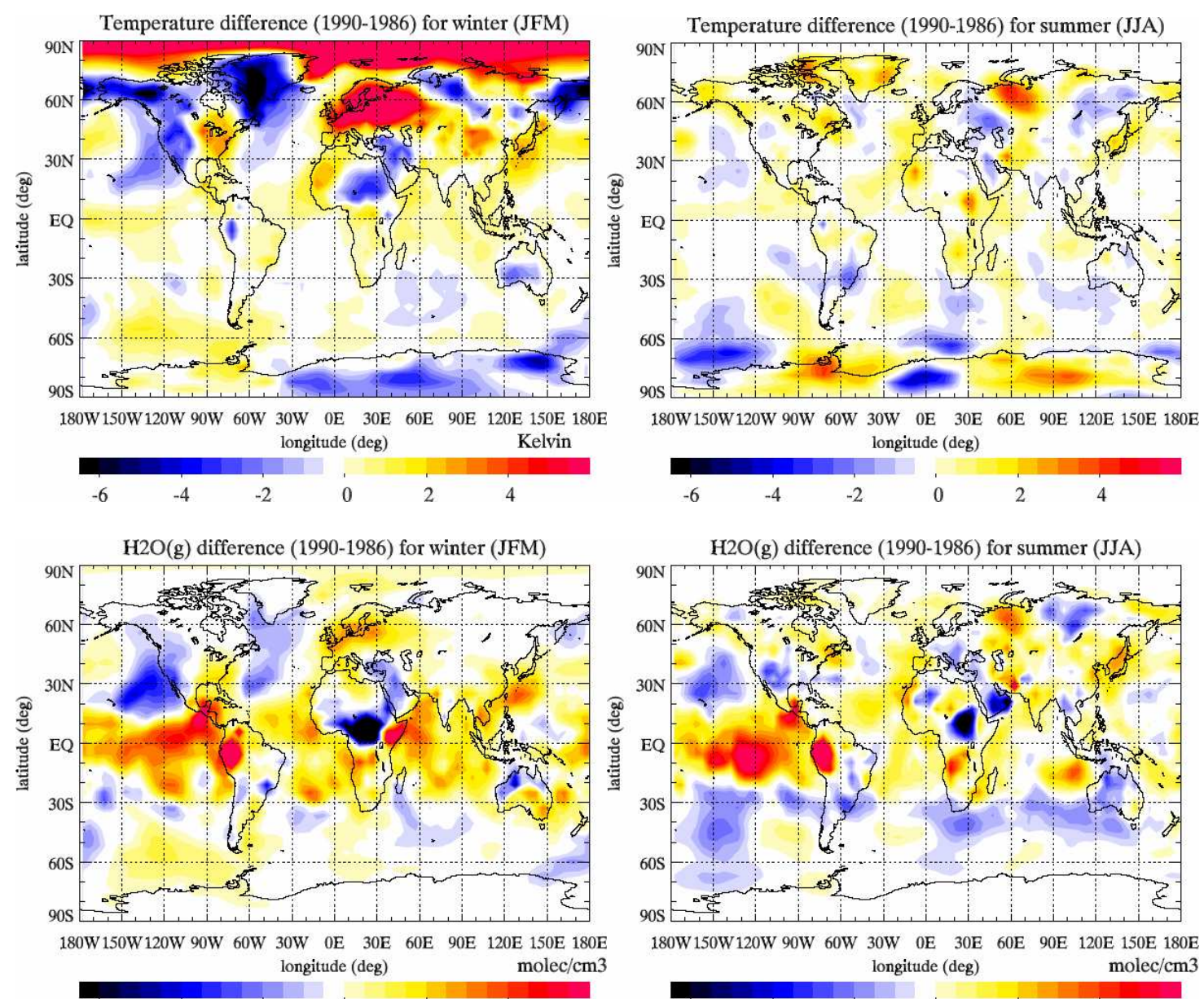

$-1.2 \mathrm{e}+17-8.0 \mathrm{e}+16-4.0 \mathrm{e}+16 \quad 1.0 \mathrm{e}+16 \quad 5.0 \mathrm{e}+16 \quad 9.0 \mathrm{e}+16$

$-1.2 \mathrm{e}+17-8.0 \mathrm{e}+16-4.0 \mathrm{e}+16 \quad 1.0 \mathrm{e}+16 \quad 5.0 \mathrm{e}+16 \quad 9.0 \mathrm{e}+16$
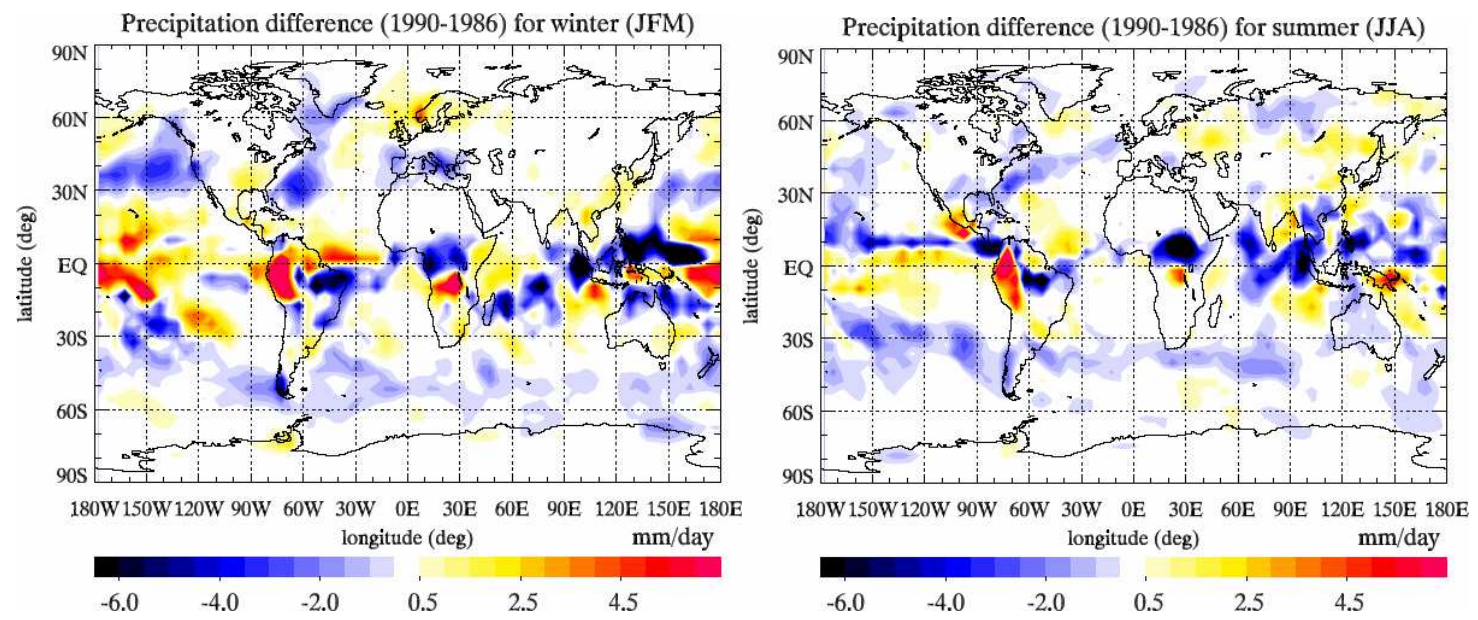

Fig. 1. Difference in temperature (top panels), water vapour (medium panels) and precipitation (bottom panels) for the year 1990 compared to 1986, integrated over two seasons, winter (JFM, to avoid December from another year) and summer (JJA). Red means increase in the year 1990 compared to 1986 and blue means decrease.

The present study aims to provide the variability of the SOA distributions and thus a measure for the robustness of the conclusions on human induced changes despite the associated uncertainties in modeling SOA chemical formation in the global troposphere (Tsigaridis and Kanakidou, 2003; Pun et al., 2003; Kanakidou et al., 2005). Multiphase 
chemistry of organics that contributes to the SOA formation in the atmosphere (Hermann et al., 2003; Ervens et al., 2004; Tolocka et al., 2004; Kalberer et al., 2004; Claeys et al., 2004b; Barsanti and Pankow, 2004) is until now neglected in SOA global chemistry/transport model (CTM) studies due to the very limited knowledge of the relevant chemical mechanisms.

To investigate the natural component of the fluctuations of the SOA chemical production and atmospheric levels, the present study takes into account the changes (i) in meteorology as observed and (ii) in biogenic emissions. An 11year global simulation has been performed with the TM3 model (Tsigaridis and Kanakidou, 2003) using the European Centre for Medium-Range Weather Forecasts (ECMWF) ERA15 reanalysis meteorology for the years 1983-1993 to drive the transport, and monthly and annually varying biogenic volatile organic compounds (BVOC) emissions. These emissions have been computed by the dynamic vegetation model ORCHIDEE constrained by the ISLSCP2 (International Satellite Land-Surface Climatology Project, Initiative II Data Archive, NASA; Hall et al., 2004) satellite-based climate forcing for the corresponding years (Lathière et al., $2005^{1}$. All other emissions have been kept constant to those of the year 1990 (Olivier et al., 1996). Additional simulations have been performed for the years 1986 and 1990 to analyse the computed changes in the SOA budget and tropospheric burden. The choice of these two years has been based on their meteorological conditions: in general, the year 1986 has been colder and drier than 1990, as can be seen in Fig. 1. As a consequence of the climate variability, the biogenic VOC emissions calculated by ORCHIDEE are higher in $1990\left(801 \mathrm{Tg} \mathrm{Cy}^{-1}\right)$ compared to $1986\left(756 \mathrm{Tg} \mathrm{Cy}^{-1}\right)$.

\section{Models description}

\subsection{Global chemistry/transport model - TM3}

The model used for the present study is the well-documented off-line chemical transport model TM3 (Houweling et al., 1998; Dentener et al., 1999; Jeuken et al., 2001). The model has a horizontal resolution of $3.75^{\circ} \times 5^{\circ}$ in latitude and longitude, and 19 vertical hybrid layers from the surface to $10 \mathrm{hPa}$. Roughly, 5 layers are located in the boundary layer, 8 in the free troposphere and 6 in the stratosphere. The model's input meteorology varies every $6 \mathrm{~h}$ and comes from the ECMWF ERA15 re-analysis data-archive (Gibson et al., 1997; http://www.ecmwf.int/research/era/ERA-15). All anthropogenic emissions (reference year 1990) were kept constant from year to year, while ozone boundary conditions

\footnotetext{
${ }^{1}$ Lathière, J., Hauglustaine, D. A., De Noblet-Ducoudré, N., Friend, A., Viovy, N., Polcher, J., and Folberth, G.: Impact of climate variability and land use changes on global biogenic volatile organic compounds emissions in a dynamic vegetation model, Atmos. Chem. Phys. Discuss., submitted, 2005.
}

vary based on TOMS data. For the present study the spatial and temporal biogenic emissions (isoprene, terpenes and other VOC) are the monthly mean emissions calculated by the ORCHIDEE model instead of the GEIA recommendations (Guenther et al., 1995). In addition, SOA formation from isoprene oxidation has been simulated by applying a $0.2 \%$ molar conversion factor (Claeys et al., 2004a). Multiphase chemistry that may produce additional organic aerosol mass (Kanakidou et al., 2005 and references therein) is not taken into account. This approach requires improvement, as soon as kinetic data will become available. The model includes coupled gas-phase chemistry and secondary aerosol formation calculations together with primary carbonaceous particles. Sea-salt and dust particles are not considered in the present study. The model parameterizations with regard to SOA production and fate in the atmosphere have been described in detail by Tsigaridis and Kanakidou (2003) and outlined below.

The SOA concentration is calculated based on the equilibrium partitioning into an absorptive organic matter phase (Pankow, 1994a, 1994b; Odum et al., 1996). The partitioning coefficients of each SOA species are a function of the vapor pressure of the species, of air temperature and of the chemical composition of the aerosol on which it partitions. A two-product model approximation (Hoffmann et al., 1997; Odum et al., 1997) is being used to represent SOA formation on line with the VOC gas-phase chemistry. This approximation, contrary to explicit chemistry schemes (Derwent et al., 2003; Bonn and Lawrence, 2005), is the same both for high and low $\mathrm{NO}_{x}$ environments and uses constant stoichiometric coefficients for the formation of semi-volatile products that lead to aerosols. This can be justified, since there is not enough understanding of the high $\mathrm{NO}_{x}$ system with regard to SOA production (Kanakidou et al., 2005). The wet deposition of the gas-phase aerosol precursors depends on their solubility in cloud droplets. For the dry deposition of the gaseous species, the Ganzeveld and Lelieveld (1995) scheme has been used, which is based on the formulation developed by Wesely (1989). For the aerosol phase, wet and dry deposition is parameterized as suggested by Parungo et al. (1994) and already applied to sulphate particles in the model (Jeuken et al., 2001). Hydrophobic particles exhibit reduced dry deposition over wetted surfaces (Cooke et al., 1999) and are not removed in-cloud. All aerosols in the model have a rural continental size distribution, i.e. mostly accumulation range aerosol (Jeuken et al., 2001).

\subsection{Dynamic vegetation model - ORCHIDEE}

A detailed biogenic emission scheme, based on Guenther et al. (1995) parameterizations, is integrated in the global vegetation model ORCHIDEE (Organizing Carbon and Hydrology in Dynamic EcosystEms) (Krinner et al., 2005). ORCHIDEE is composed of 3 models and is designed either to be coupled to a general circulation model or forced by 
climatic data. The surface-vegetation-atmosphere transfer scheme SECHIBA (Schématisation des échanges hydriques à l'interface biosphere-atmosphère, Ducoudré et al., 1993; de Rosnay and Polcher, 1998) calculates processes characterized by short time-scales, ranging from a few minutes to hours, such as energy and water exchanges between the atmosphere and the terrestrial biosphere as well as the soil water budget. Parameterizations for dynamic vegetation simulation have been taken from the LPJ (Lund-Potsdam-Jena) model (Sitch et al., 2003) that is able to compute long-term changes in vegetation distribution. The third component, STOMATE (Saclay-Toulouse-Orsay Model for the Analysis of Terrestrial Ecosystems), treats other processes which can be described with a time-step of a few days, such as photosynthesis, carbon allocation, litter decomposition, soil carbon dynamics, phenology, maintenance and growth respiration. Twelve plant functional types (PFTs) are considered in ORCHIDEE on top of bare soil and cohabit in each grid point depending on the geographical location. This distinction is of great importance since the nature and the amount of the biogenic VOC emitted are very different from one vegetation type to another. However, there is insufficient information on emission rates to consider significantly more plant types. Additionally, there are too few data on emission factors for different monoterpene compounds from different plant species, and even less for a global study. This certainly leads to a non-negligible error in the speciation of terpene and ORVOC emissions, but the actual knowledge on individual compound biogenic emission rates limits more detailed calculations.

Biogenic emissions of VOC are calculated based on the well-known Guenther et al. (1995) parameterizations and take into account additional features such as the impact of leaf age on isoprene and methanol emissions. On top of the isoprene, monoterpenes, and other volatile organic compounds (OVOC) emissions considered in previous works, ORCHIDEE also calculates explicitly biogenic emissions of methanol, acetone, acetaldehyde, formaldehyde, acetic and formic acids. The general formula is:

$F=\mathrm{LAI} * s * E_{f} * C_{T} * C_{L} * L_{a}$

where $F$ is the flux of the biogenic species considered, given in $\mu \mathrm{g} \mathrm{C} \mathrm{m}^{-2} \mathrm{~h}^{-1}$; LAI is the leaf area index in $\mathrm{m}^{2} \mathrm{~m}^{-2}$, calculated step by step by the model; unlike Guenther et al. (1995) the specific leaf weight $s$ in $\mathrm{g} \mathrm{m}^{-2}$ is calculated by ORCHIDEE depending on the considered PFT; $E_{f}$ is the emission factor in $\mu \mathrm{g} \mathrm{Cg}^{-1} \mathrm{~h}^{-1}$ prescribed for each PFT and biogenic species (Guenther et al., 1995, 2000; MacDonald and Fall, 1993; Kesselmeier and Staudt, 1999; Janson and de Serves, 2001). $C_{T}$ and $C_{L}$ are adjustment factors which account for the influence of leaf temperature and light on biogenic emissions: a light and temperature dependency is considered for isoprene emissions and radiation extinction inside the canopy is taken into account, so that shaded leaves emit much less isoprene than sunlit ones, and only temperature dependency is taken into consideration for all other compounds. Thus the temperature dependency for isoprene is expressed by

$C_{T}=\frac{\exp \frac{C_{T 1}\left(T-T_{S}\right)}{R T_{S} T}}{1+\exp \frac{C_{T 2}\left(T-T_{M}\right)}{R T_{S} T}}$

and for all other compounds

$C_{T}=\exp \left(\beta\left(T-T_{S}\right)\right)$.

The light dependency considered only for isoprene is expressed by the factor $C_{L}$ :

$C_{L}=\frac{a C_{L 1} Q}{\sqrt{1+a^{2} Q^{2}}}$

For the above mentioned equations, $T$ is leaf temperature $(\mathrm{K}), Q$ is the flux of photosynthetic active radiation (PAR; $\mu$ mol phot $\left.\mathrm{m}^{-2} \mathrm{~s}^{-1}\right), T_{s}$ is leaf temperature at standard conditions $(303 \mathrm{~K}), R$ is the gas constant $\left(8.314 \mathrm{~J} \mathrm{~K}^{-1} \mathrm{~mol}^{-1}\right)$; $C_{T 1}\left(95000 \mathrm{~J} \mathrm{~mol}^{-1}\right), C_{T 2}\left(230000 \mathrm{~J} \mathrm{~mol}^{-1}\right), T_{M}(314 \mathrm{~K}), \beta$ $\left(0.09 \mathrm{~K}^{-1}\right), \alpha(0.0027)$ and $C_{L 1}(1.066)$ are empirical coefficients. Since the ORCHIDEE model does not calculate the leaf temperature, we use instead the "surface" temperature, that reflects the radiative budget including soil surface and canopy, and not the air temperature, as done by Guenther et al. (1995). The GEIA inventory for isoprene and terpenes is $20 \%-30 \%$ higher than that of ORCHIDEE. This difference is below the uncertainty of a factor of 2 to 3 associated with the BVOC emissions.

Several studies (Guenther et al., 2000; MacDonald and Fall, 1993) underline the impact of leaf age on the emission capacity and highlight that young leaves emit less isoprene but more methanol than mature ones and that old leaves have a strongly reduced emission capacity. We thus assigned a biogenic emissions activity factor $L_{a}$ (Eq. 1) depending on the leaf age classes given in ORCHIDEE, assuming that mature and old leaves emission efficiency is half the one of young leaves in the case of methanol emissions, and that young and old leaves emit 3 times less isoprene than mature ones (Guenther et al., 1999). For the present study ORCHIDEE has been forced by ISLSCP2 satellite observations (http://islscp2.sesda.com/ISLSCP2_1/html_pages/ islscp2 home.html) suitable for use in models of the biosphere. Note that the ECMWF assimilated ERA-15 dataset has been used by the TM3 model. These datasets (ISLCP2 and ECMWF) are both based on observations, limiting therefore possible inconsistencies between the derived biogenic emissions and the TM3 simulations.

According to these calculations, the mean emissions over the 1983-1993 period equal $458 \mathrm{Tg} \mathrm{Cy}^{-1}$ for isoprene, $117 \mathrm{Tg} \mathrm{Cy}^{-1}$ for terpenes and $214 \mathrm{Tg} \mathrm{Cy}^{-1}$ for other VOC. A more detailed description and evaluation of the emission model is provided in Lathière et al. (2005) ${ }^{1}$. 


\section{Biogenic VOC emissions variability}

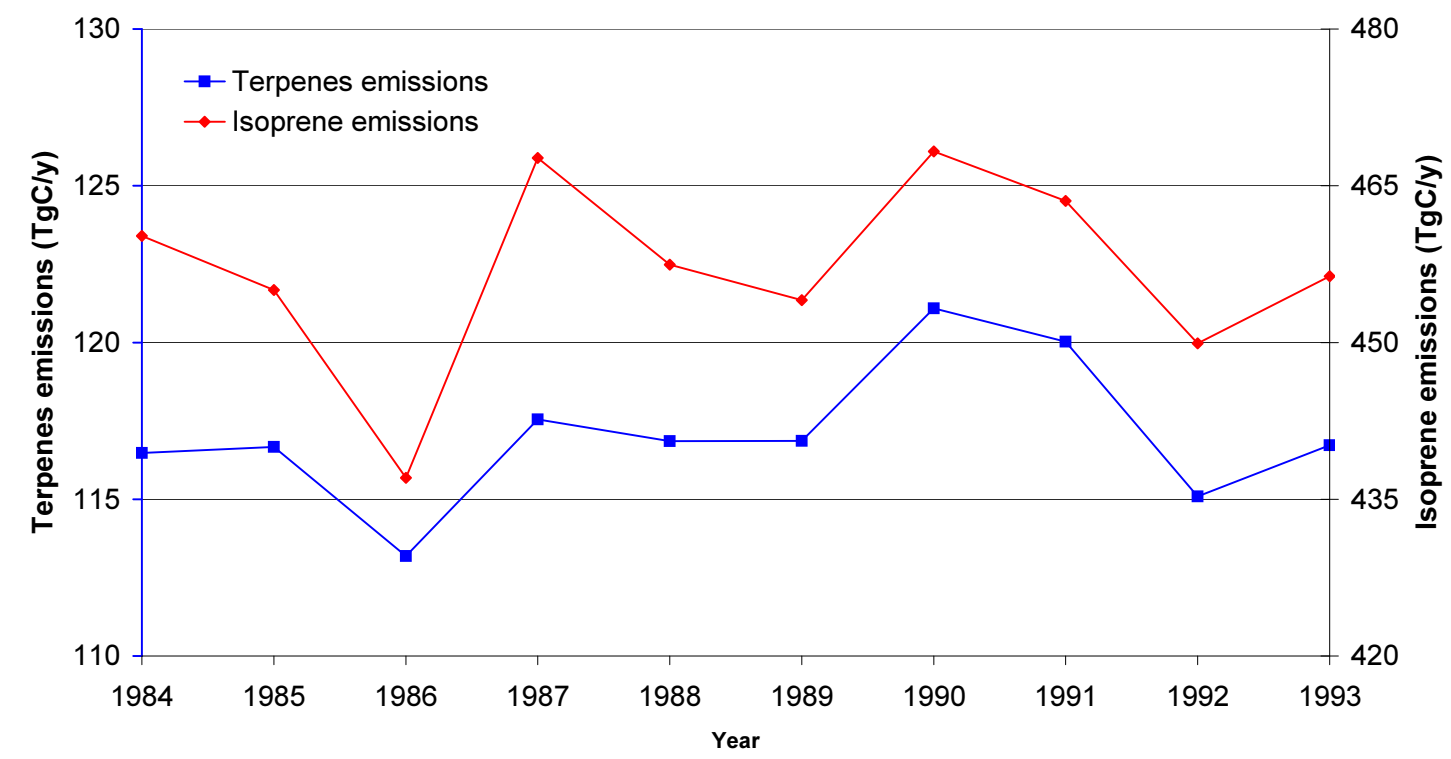

Fig. 2. Biogenic VOC emissions variability for the period 1984-1993 as calculated by the ORCHIDEE model.

\subsection{The simulations}

We performed six different TM3 simulations which are summarized as follows:

1. Interannual variability. An 11-year simulation from 1983 to 1993 has been performed, from which the first year (1983) has been used for spin up time and the next 10 years (1984-1993) are analyzed for the present study.

2. M86/E86: This simulation corresponds to the year 1986, extracted from the 11-year simulation. Biogenic emissions of VOC and meteorological fields come from the year 1986. This simulation has been arbitrary used as base case for the present study.

3. T90/E86: Same as M86/E86 but with temperature fields from the year 1990.

4. TH90/E86: Same as M86/E86 but with temperature and water cycle fields (relative humidity, rainfall, cloud cover) from the year 1990.

5. M90/E86: Same as M86/E86 but with meteorological fields from the year 1990.

6. M90/E90: This is the year 1990 simulation extracted from the 11-year simulation. Emissions and meteorological fields come from 1990.

SOA budgets are lower limits based on discussion in Tsigaridis and Kanakidou (2003) due to oligomers formation
(Kalberer et al., 2004; Tolocka et al., 2004), multiphase chemistry and cloud processes (Warneck, 2003; Ervens et al., 2004) that are not included in the present study and are expected to enhance the SOA mass production.

\section{Interannual variability in SOA budget terms for the 10-year period}

The variability of the biogenic VOC emissions calculated by ORCHIDEE during the studied 10-year period (19841993) is shown in Fig. 2. For isoprene, monoterpenes and the other VOC categories, the minimum emissions are calculated for the year $1986\left(436 \mathrm{Tg} \mathrm{Cy}^{-1}, 113 \mathrm{TgC} \mathrm{Cy}^{-1}\right.$ and $207 \mathrm{Tg} \mathrm{Cy}^{-1}$, respectively) and the maximum for the year 1990 (468 $\mathrm{Tg} \mathrm{Cy}^{-1}, 121 \mathrm{Tg} \mathrm{Cy}^{-1}$ and $221 \mathrm{Tg} \mathrm{Cy}^{-1}$, respectively). The increase in the emissions from 1986 to 1990 reaches $7 \%$ in all VOC categories, and is a result of the natural variability of the climate system (i.e. temperature and light intensity which are key parameters in biogenic emissions variability, and water cycle) with generally colder and drier 1986 than 1990 (Fig. 1). These temperature and water cycle differences are not uniformly distributed around the globe; therefore the calculated emission changes vary spatially (Fig. 3).

Figure 4 depicts the annual variability of SOA budget terms as calculated by the TM3 model for the period 1984 to 1993 that results from changes in the emissions (Figs. 2 and 3) and meteorology (Fig. 1). The global annual chemical production of SOA varies similarly to the emissions of biogenic VOC and the wet deposition of aerosols (for SOA is 

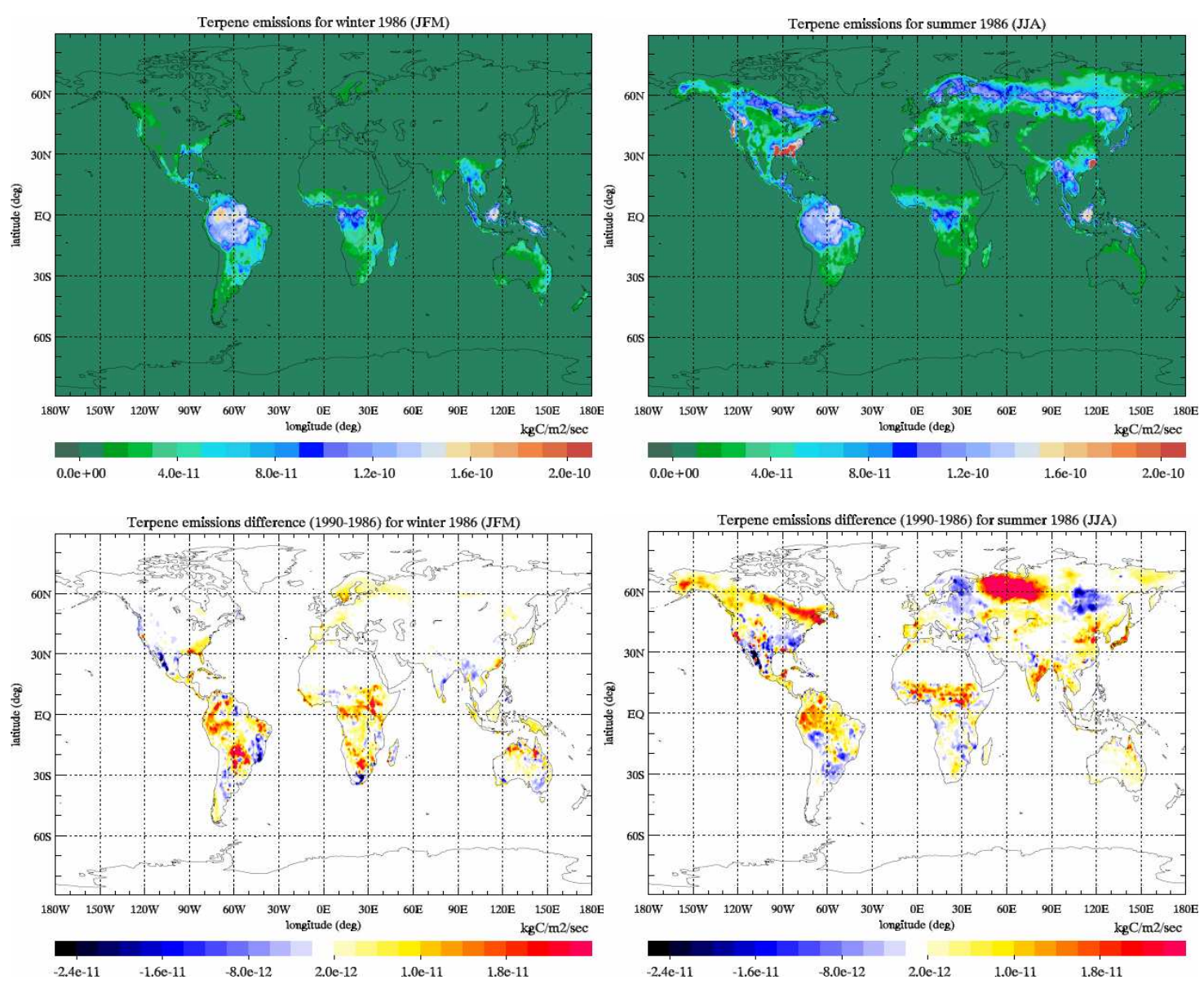

Fig. 3. Mean terpene emissions for 1986 (top panels) and differences of the mean terpene emissions (bottom panels) for winter (JFM, left panels) and summer (JJA, right panels) as calculated by the ORCHIDEE model for the year 1990 compared with those of the year 1986, in $\mathrm{kg} \mathrm{C} \mathrm{m}^{-2} \mathrm{~s}^{-1}$.

shown in Fig. 4). SOA burden in the model domain presents its minimum value of $0.143 \mathrm{Tg}$ in 1986 when biogenic VOC emissions are calculated to minimize. The maximum SOA burden is however computed for the year 1991 that is subject to high BVOC emissions (although the maximum emissions are calculated for 1990) but also to somehow lower than 1990 precipitation. The burden of all aerosols included in the model has increased by $1.8 \%$ from 1986 to 1990 , with $0.8 \%$ attributed to the change in the meteorological conditions and the remaining $1 \%$ to the increase in SOAb burden (by $11.5 \%$ ). Therefore, the natural variation of SOAb appears to be the most important contributor to the variation of the aerosol burden due to the natural changes. Note that seasalt and dust are not considered in the present study.

The variation of the SOA production efficiency of the BVOC emissions for the 10-year period is shown in Fig. 5 as the ratio $\frac{\text { Global annual chemical SOAb production }}{\text { SOAb precursor VOC emissions }}$ normalized by the average ratio $(0.115)$ for the whole period (squares). The ratio $\frac{\text { Global SOAb burden }}{\text { SOAb precursor VOC emissions }}$ nor- malized by the average ratio $\left(8.2610^{-4}\right)$ for the whole period (triangles) is also depicted as a measure of effective SOA yield of the emissions. In 1986 when the emissions are the lowest of the 10-year period, the chemical production efficiency and the burden efficiency are the lowest too. An interesting remark is that for the years 1990 and 1991, when the emissions are the highest, the chemical production efficiency is below the average of the 10-year period. This could result from high removal processes during these two years, which eliminate aerosols and corresponding gas-phase species from the atmosphere more efficient and thus slow down the aerosol production. The SOA production potential of the emissions is highest in the years 1987-1989 and 1992-1993. The difference in the interannual behavior of the above discussed indices of SOA occurrence in the troposphere is largely due to the discussed involvement of the wet removal processes. Additionally, since 1990 is warmer than 1986, enhanced evaporation could result from higher saturation vapor pressure of SOA precursor species, thus reducing the condensation rate of semi-volatile compounds. However, this effect is expected to be of minor importance, as it will be discussed later. 


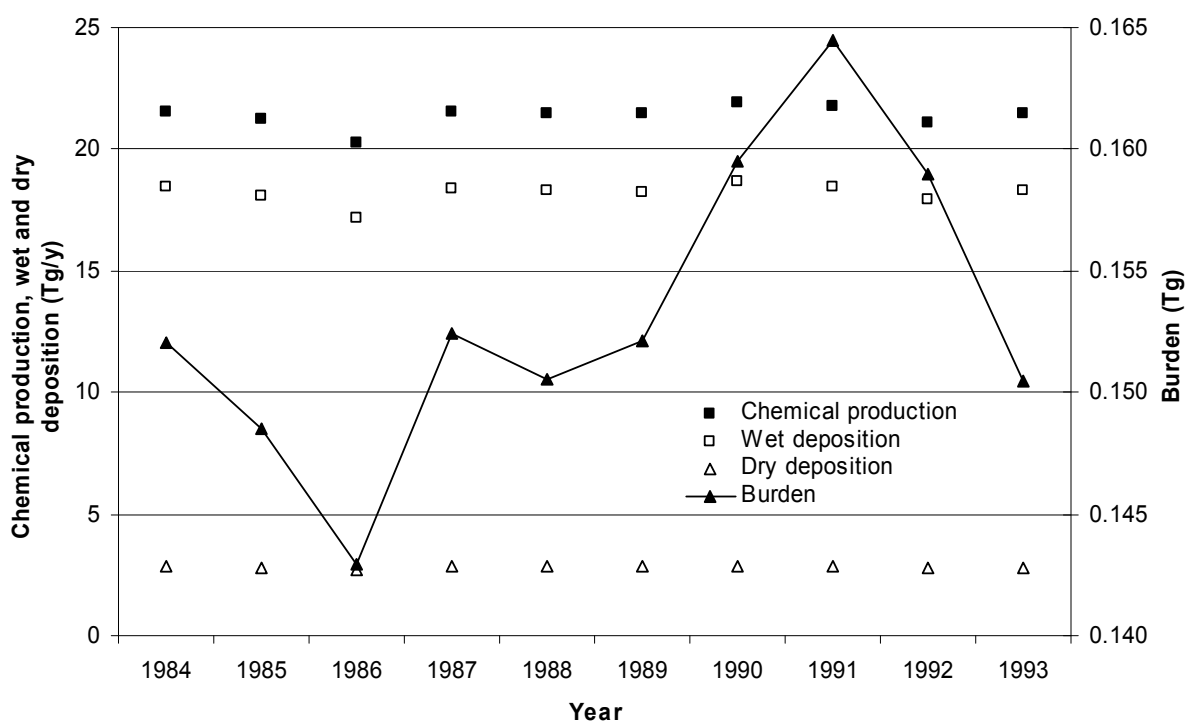

Fig. 4. Variability of the global annual chemical production of SOA (solid squares), of the SOA burden (solid triangles), of the global annual SOA removal by wet (open squares) and dry (open triangles) deposition from 1984 to 1993.

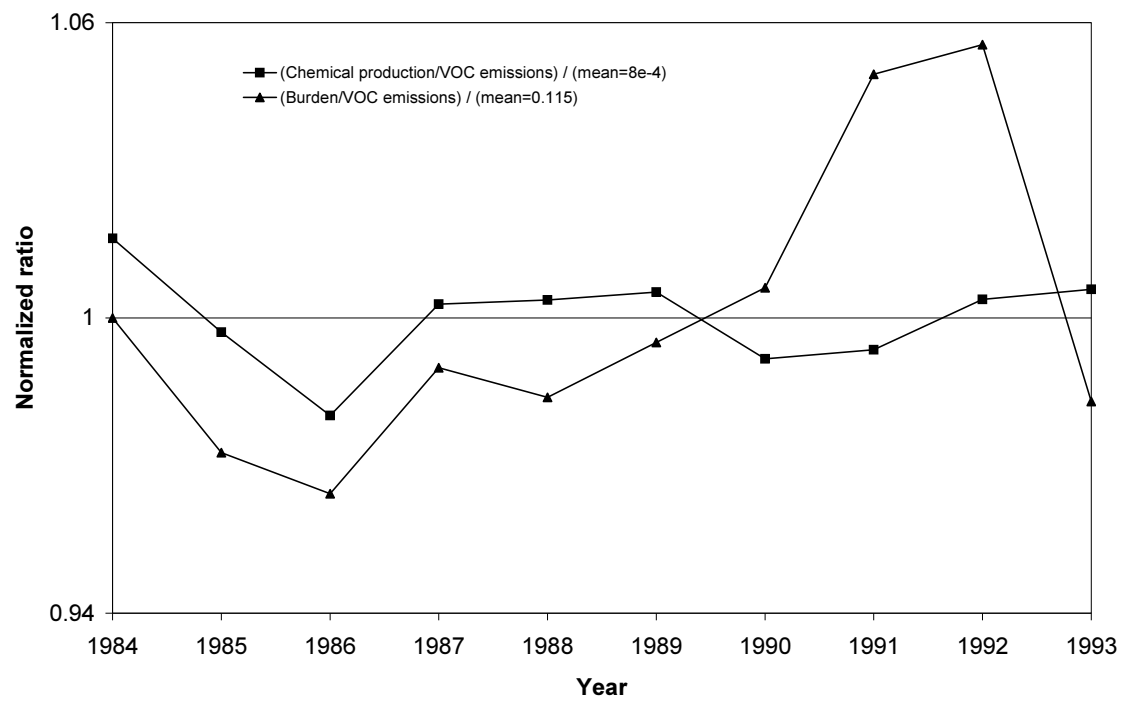

Fig. 5. Squares: Normalized ratio of the SOA chemical production (squares) and burden (triangles) to the VOC emissions of the specific year. The ratios are normalized dividing by the mean ratio of $8.10^{-4}$ and 0.115 respectively, for the period 1984-1993. Values larger (smaller) than 1 indicate higher (lower) ratios than the 10 -year period mean value.

SOA are not only formed in the lower troposphere where most of the oxidation of the parent VOC occurs. The gasphase products of the oxidation of the emitted biogenic or anthropogenic VOC can be transported and condense in a distant area, where the meteorological conditions favour condensation. Air circulation affects the SOA budget, since air masses are transported from areas with high temperatures to areas with lower temperatures, for instance towards the high troposphere, where the condensation of the semivolatile species is favoured and leads to SOA production. This process is of great importance both for the biogenic SOA
(SOAb: that comes from biogenic parent VOC oxidation) and for the anthropogenic SOA (SOAa: that comes from anthropogenic parent VOC oxidation). We calculate that $60 \%$ of the net chemical production of the SOAa and $70 \%$ of the $\mathrm{SOAb}$ occur below about $300 \mathrm{hPa}$ (first 9 model levels). This means that roughly $1 / 3$ of the total chemical production of SOA is calculated to occur in the upper troposphere/lower stratosphere. Accordingly, corresponding SOA burden calculations show that about $60 \%$ of the SOAa and $65 \%$ of the SOAb mass is located in the lower and middle troposphere (below $300 \mathrm{hPa}$ ). This vertical distribution of the SOA 
Table 1. Global SOA budget and its variability between 1986 and 1990 due to meteorology and to changes in biogenic emissions.

\begin{tabular}{|c|c|c|c|c|c|c|c|c|c|c|}
\hline & \multicolumn{2}{|c|}{ Burden } & \multicolumn{2}{|c|}{ Wet deposition } & \multicolumn{2}{|c|}{ Dry deposition } & \multicolumn{4}{|c|}{ Chemical production } \\
\hline & \multirow{2}{*}{$\begin{array}{c}\text { SOAa } \\
\text { Gg }\end{array}$} & \multirow{2}{*}{$\begin{array}{c}\mathrm{SOAb} \\
\mathrm{Gg}\end{array}$} & \multirow{2}{*}{$\begin{array}{c}\text { SOAa } \\
\operatorname{Tg~}^{-1}\end{array}$} & \multirow{2}{*}{$\begin{array}{c}\text { SOAb } \\
\operatorname{Tg}^{-1}\end{array}$} & \multirow{2}{*}{$\begin{array}{c}\text { SOAa } \\
{\operatorname{Tg~} \mathrm{y}^{-1}}\end{array}$} & \multirow{2}{*}{$\begin{array}{c}\mathrm{SOAb} \\
\mathrm{Tg} \mathrm{y}^{-1}\end{array}$} & \multicolumn{2}{|c|}{ SOAa } & \multicolumn{2}{|c|}{ SOAb } \\
\hline & & & & & & & $\operatorname{Tg}^{-1}$ & $\%^{a}$ & $\operatorname{Tg~}^{-1}$ & $\%^{a}$ \\
\hline M86/E86 & 12.2 & 142.9 & 1.45 & 17.2 & 0.11 & 2.73 & 1.57 & 0 & 20.28 & 0 \\
\hline T90/E86 & 12.3 & 143 & 1.4 & 17. & 0.1 & 2.7 & 1.58 & 0.6 & 20.19 & -0.4 \\
\hline TH90/E86 & 16.1 & 189 & 1.5 & 17.6 & 0.1 & 2.7 & 1.6 & 7.6 & 20.68 & 2.0 \\
\hline M90/E86 & 12.5 & 146.8 & 1.44 & 17.83 & 0.1 & 2.67 & 1.56 & -0.6 & 20.26 & -0.1 \\
\hline M90/E90 & 12.5 & 159.5 & 1.45 & 18.67 & 0.11 & 2.89 & 1.56 & -0.6 & 21.94 & 8.2 \\
\hline
\end{tabular}

a: \% difference compared to M86/E86 simulation

burden is slightly different than that of the chemical production due to enhanced removal of the particles by wet and dry deposition at the lowest altitudes. The interannual variability of these numbers is insignificant (vary about $1-2$ percent units) for the whole 10-year studied period.

\section{What controls the variability of the SOA budget terms}

In order to study the factors that influence the interannual variability of the SOA budget terms (chemical production, destruction by deposition, total budget) five additional simulations have been performed as described in Sect. 2.3. The year 1986 (lowest emissions of biogenic VOC and chemical production of SOA for the studied years) has been chosen for comparison with 1990 (highest emissions and chemical production).

The results for the five different simulations with regard to SOA budget terms are shown in Table 1. As also indicated in this table, the chemical formation of total SOA is controlled by the biogenic VOC, since the biogenic fraction SOAb is the major contributor to the total SOA (Tsigaridis and Kanakidou, 2003). For the same amount of precursor VOC emissions (M86/E86 vs. TH90/E86) the chemical production of SOA is controlled by temperature and water cycle (relative humidity, precipitation, cloud cover), reduced by $0.4 \%$ and increased by about $2.4 \%$, respectively, when changing from 1986 to 1990 fields.

Temperature changes affect almost all processes involved in the chemical production of SOA. They affect (i) the emissions (7\% increase from 1986 to 1990), (ii) the reaction rates of the emitted VOC, thus affecting the rate of chemical production of the gas-phase aerosol precursors; this resulted in $0.3 \%$ enhancement of the contribution of $\mathrm{O}_{3}$ reaction to the chemical loss of BVOC, (iii) the partitioning of secondary organic matter between gas and aerosol phase leading to reduced production of the SOA with increasing temperature (about $16 \%$ to $8 \%$ reduction in the partitioning coefficients for 1 deg increase, for temperatures around 220 and 320, respectively). The observed reduced rainfall over most of precursor VOC source regions as recorded by the ECMWF me- teorological data, results in the presence of more pre-existing particulate matter available for condensation of semi-volatile compounds and thus in higher SOA mass production. This points the need of accurate knowledge of the changes in the spatial pattern of the meteorological parameters and the biogenic emissions.

Important feedback mechanisms are also related to transport in the atmosphere and affect SOA chemical production, which makes simulations M86/E86 and M90/E86 to have only small changes in the chemical production of SOA, i.e. transport compensates for the $2 \%$ changes calculated when comparing TH90/E86 with M86/E86.

\section{SOA optical depth: spatial and temporal variability}

In order to calculate the optical depth (OD) of the particles we used the approach of Kiehl and Briegleb (1993):

$O D(\lambda)=f(R H, \lambda) B(\lambda) a$

Where $O D(\lambda)$ is the OD of the aerosol at a wavelength $\lambda$, $B(\lambda)$ is the mass extinction efficiency (extinction coefficient per unit of aerosol mass at relative humidity $(\mathrm{RH})<40 \%$; Table 2), $a$ is the aerosol column burden and $f(\mathrm{RH}, \lambda)$ is the relative increase of the scattering coefficient at given $\mathrm{RH}$ to the scattering at low $(<40 \%) \mathrm{RH}$ (based on a polynomial fit by Veefkind (1999) for sulfate aerosols). This approach has been used for all types of aerosols that are not hydrophobic (part of carbonaceous aerosols, see Tsigaridis and Kanakidou (2003) for details). It has to be noted that treating carbonaceous hydrophilic aerosols like sulfate, overestimates the amount of water associated to the aerosol, and has to be viewed as an upper limit of carbonaceous aerosol contribution to OD. The lower limit can be calculated considering dry aerosol. According our calculations, the aerosol associated water increases the OD by about $30 \%$. A geometric mean radius of $0.05 \mu \mathrm{m}$ and a geometric standard deviation of 2.0 has been adopted for all aerosol types in the model.

The calculated OD of SOA (OD_SOA) presents a high spatial (Fig. 6) and temporal (not shown) variability, reflecting that of the emissions of biogenic VOC (7\%), oxidant levels in 

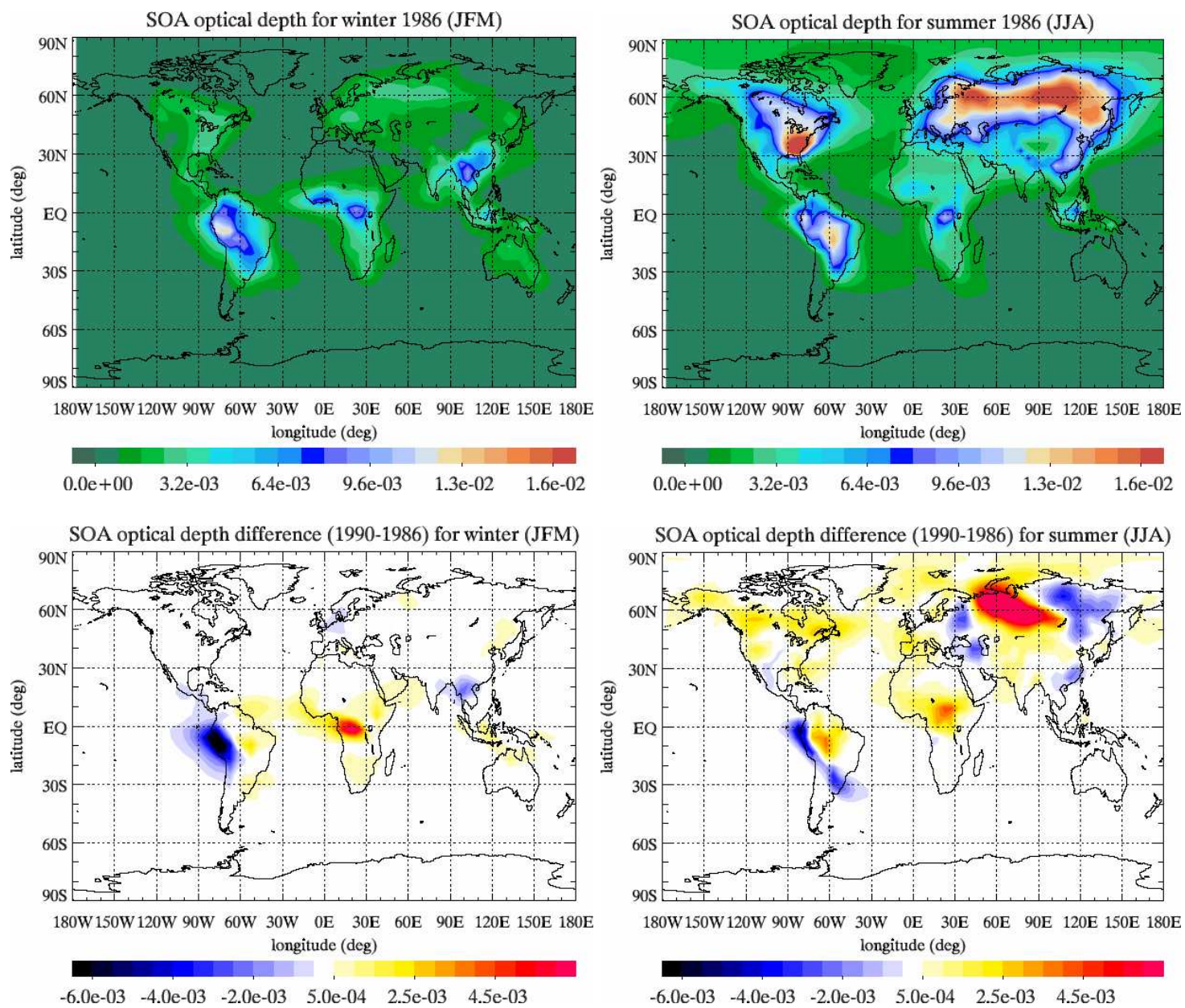

Fig. 6. OD_SOA for 1986 (top panels) and the difference of OD_SOA for 1986 from that for 1990 (lower panels) for winter (left panels) and summer (right panels).
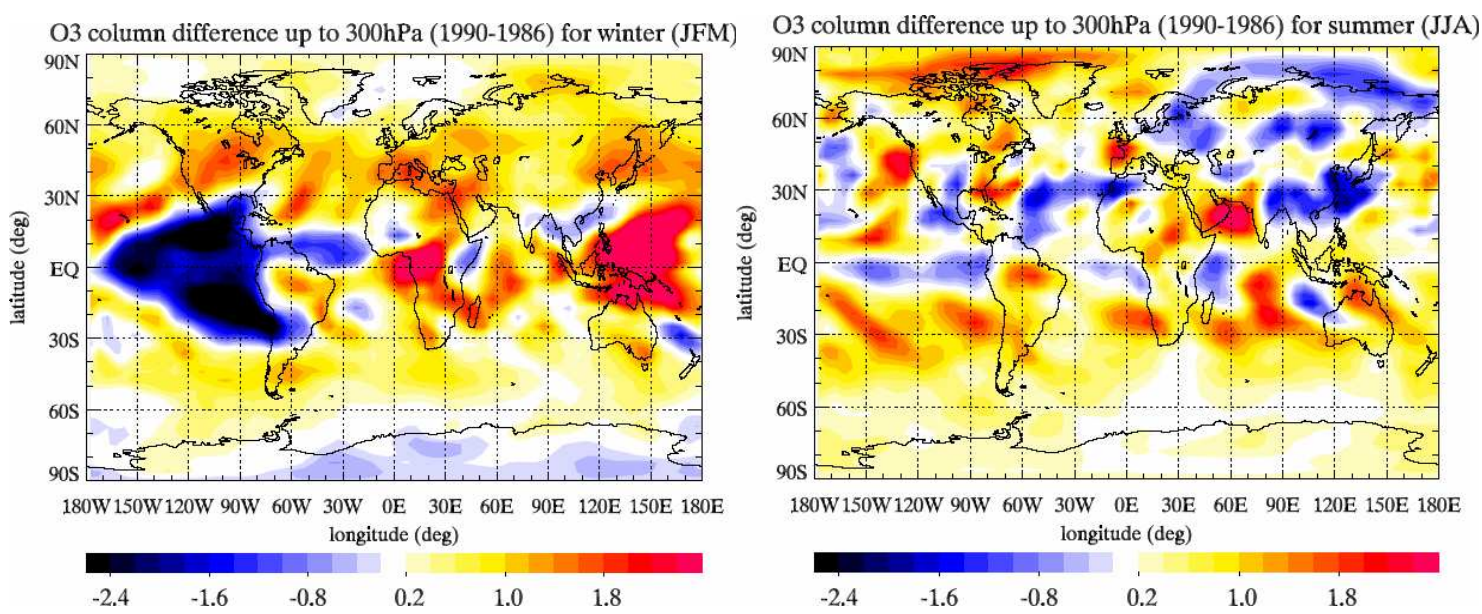

Fig. 7. Tropospheric $\mathrm{O}_{3}$ column (up to $300 \mathrm{hPa}$, in DU) difference between 1986 and 1990 for winter (left panel) and summer (right panel). Red means increased $\mathrm{O}_{3}$ in 1990 compared with 1986 and blue means reduced $\mathrm{O}_{3}$ in 1990 compared with 1986. 

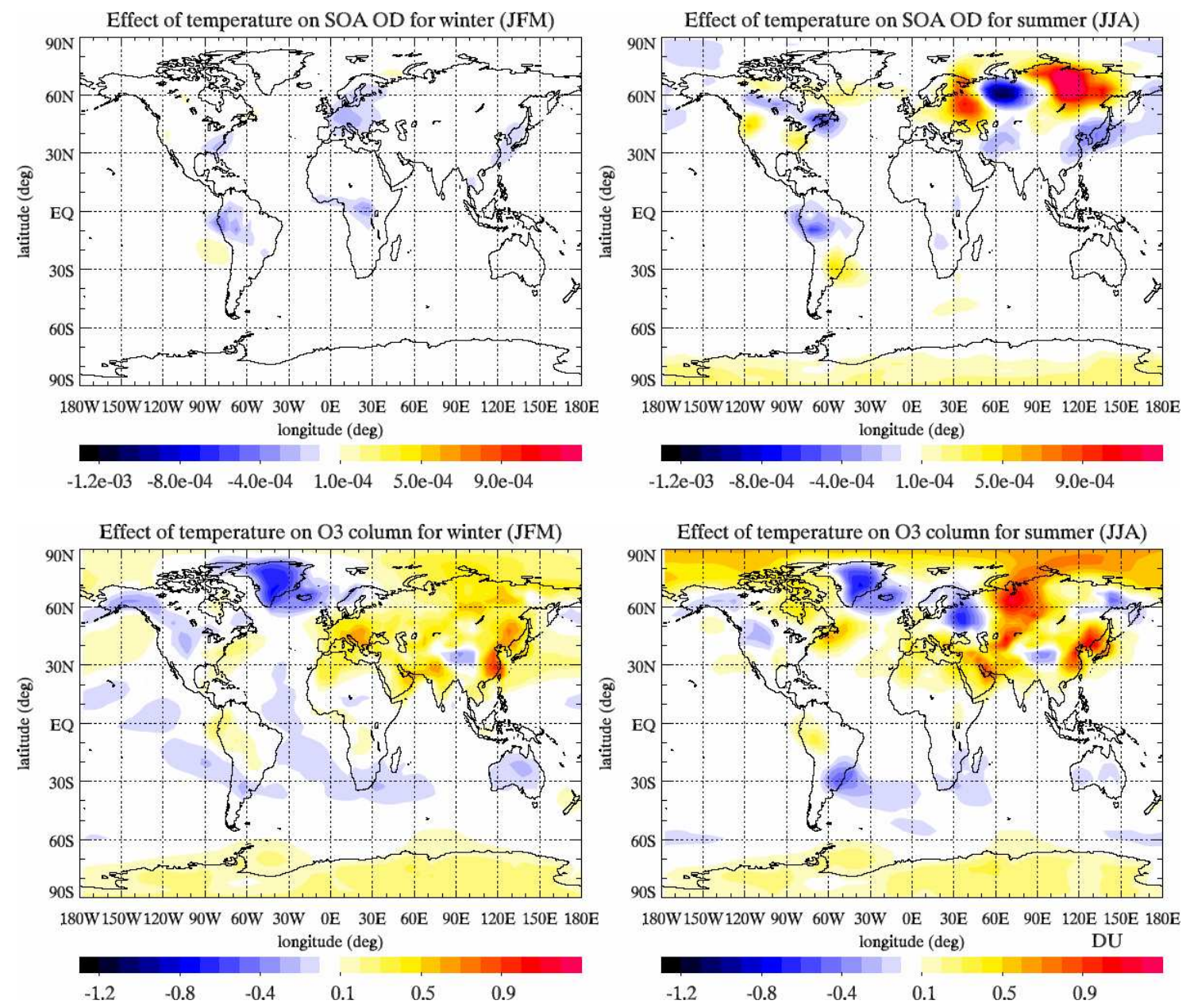

Fig. 8. Impact of temperature on OD_SOA (top panels) and $\mathrm{O}_{3}$ (bottom panels) for winter (left panels) and summer (right panels). Red means increased OD_SOA or $\mathrm{O}_{3}$ column resulting from the temperature of 1990 compared with that of 1986 (simulations T90/E86 vs. M86/E86, respectively). Blue means decreased OD_SOA or O 3 column resulting from the temperature of 1990 compared with that of 1986.

Table 2. Extinction coefficients at $555 \mathrm{~nm}$ used in the OD calculations.

\begin{tabular}{ccc}
\hline Aerosol component & $B\left(\mathrm{~m}^{2} \mathrm{~g}^{-1}\right)$ & Reference \\
\hline $\mathrm{SO}_{4}$ & 5 & Jeuken et al. (2001) \\
$\mathrm{NO}_{3}$ & 5 & Jeuken et al. (2001) \\
$\mathrm{BC}$ & 9 & Liousse et al. (1996); \\
& & Tegen et al. (1997) \\
Primary OA & 4 & Liousse et al. (1996) \\
SOA & 4 & Liousse et al. (1996) \\
\hline
\end{tabular}

the troposphere $\left(5 \% \mathrm{OH}, 4 \% \mathrm{O}_{3}, 4 \% \mathrm{NO}_{3}\right.$ on a global scale) and meteorological conditions (mainly temperature and relative humidity) as discussed in Sect. 4. The calculated differences in OD_SOA resulting from changes both in meteorology and biogenic emissions (M90/E90 vs. M86/E86) are also shown in Fig. 6 (lower panels) and reveal high variabil- ity with both positive and negative values and an overall effect of an increased global burden of SOA. The trend of increase or decrease of OD_SOA follows mainly the trend of the emissions difference between 1986 and 1990. However, over some areas changes in rainfall that is the main aerosol removal process affect strongly the OD_SOA (increased rainfall leads to reduced OD_SOA).

To further analyze SOA changes, we focus on $\mathrm{O}_{3}$ that is the main oxidant involved in SOA formation in our model. The corresponding differences in the calculated tropospheric $\mathrm{O}_{3}$ columns (from the surface to $300 \mathrm{hPa}$ ) are shown in Fig. 7. They reflect the increased production of $\mathrm{O}_{3}$ in $\mathrm{VOC}$ limited areas when VOC emissions are higher due to higher temperature in 1990 than in 1986 and the enhanced loss of $\mathrm{O}_{3}$ where relative humidity has been increased. In areas that were getting drier (Fig. 1) $\mathrm{O}_{3}$ has been increased, since the reaction of $\mathrm{O}^{1} \mathrm{D}$ with water vapor, acting as a net $\mathrm{O}_{3}$ loss, has been depressed. 



Fig. 9. Impact of water cycle on OD_SOA (top panels) and $\mathrm{O}_{3}$ (bottom panels) for winter (left panels) and summer (right panels). Red means increased OD_SOA or $\mathrm{O}_{3}$ column resulting from the water cycle of 1990 compared with that of 1986 (simulations TH90/E86 vs. T90/E86, respectively) and blue means decreased OD_SOA or $\mathrm{O}_{3}$ column resulting from the water cycle of 1990 compared with that of 1986.

Temperature is another important factor controlling the SOA distribution. The calculated differences between simulations T90/E86 and M86/E86 are the effect of temperature change between 1990 and 1986 and are depicted in Fig. 8 both for the OD_SOA and $\mathrm{O}_{3}$ column. When temperature increases, the condensation of the semivolatile compounds present in the atmosphere is reduced, therefore the model calculates lower OD_SOA for 1990 where temperature has been increased (from 1986 to 1990; see also Fig. 1) and vice versa. Lower temperatures also imply less photochemical activity that results in reduced $\mathrm{O}_{3}$ calculated by the model.

The atmospheric water cycle also affects the OD_SOA since it drives the wet deposition of trace gases and aerosols. Additionally, the relative humidity of the air affects the amount of water present in the aerosols, and thus their extinction coefficient. The net result of these processes is shown in Fig. 9 that depicts the spatial variation of the effect of water cycle on OD_SOA and $\mathrm{O}_{3}$ column. In general, $\mathrm{O}_{3}$ is increasing where the relative humidity decreases. Since $\mathrm{O}_{3}$ reaction is the main oxidant that produces SOA in the model, an increase in the OD_SOA is also calculated.

The seasonality of the calculated OD_SOA is strong (OD_SOA during summer is more than double that of winter; Fig. 10), but the interannual variability is weak (about $12 \%$; not shown) and of the same order of magnitude with the natural variability of the biogenic emissions. OD_SOA maximizes during summer, when both tropical and temperate/boreal forests emit large amounts of biogenic VOC, and minimizes during winter when the emissions of biogenic VOC are important only in the tropical forests that receive large amounts of solar radiation year-round. According to our model calculations that neglect sea-salt and dust, OD_SOA contributes to the total global average OD by about $5 \%$ with other contributors being sulphate $(57 \%)$, black carbon $(14 \%)$, nitrate $(13 \%)$ and primary organic carbon $(11 \%)$. These contributions are subject to significant spatial and temporal variations. 


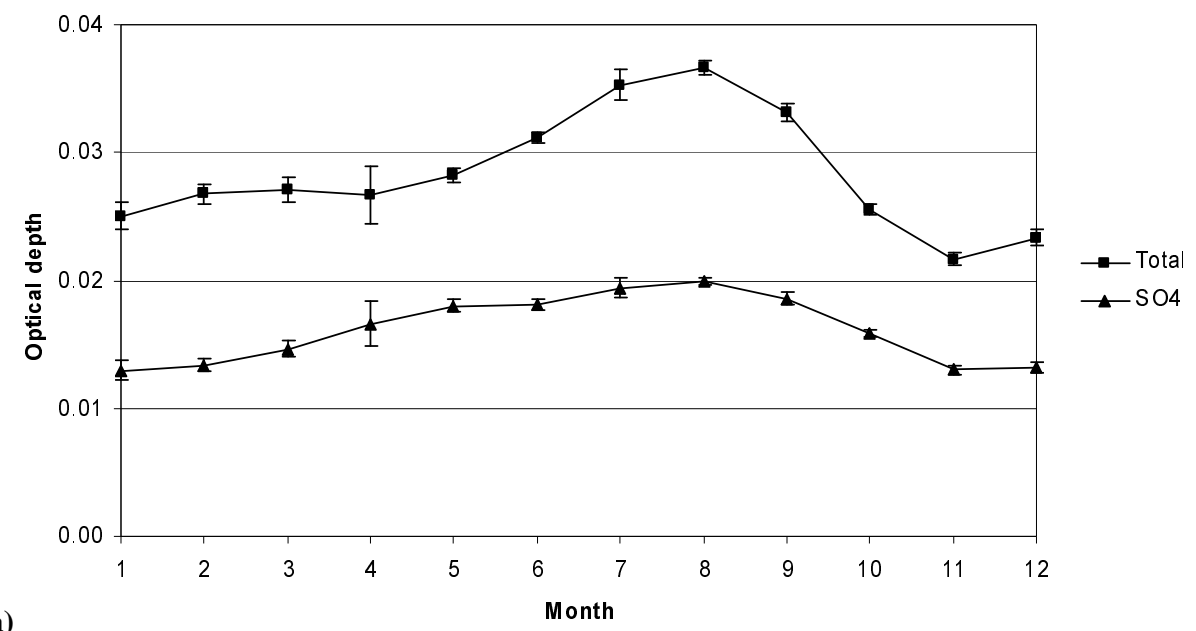

(a)

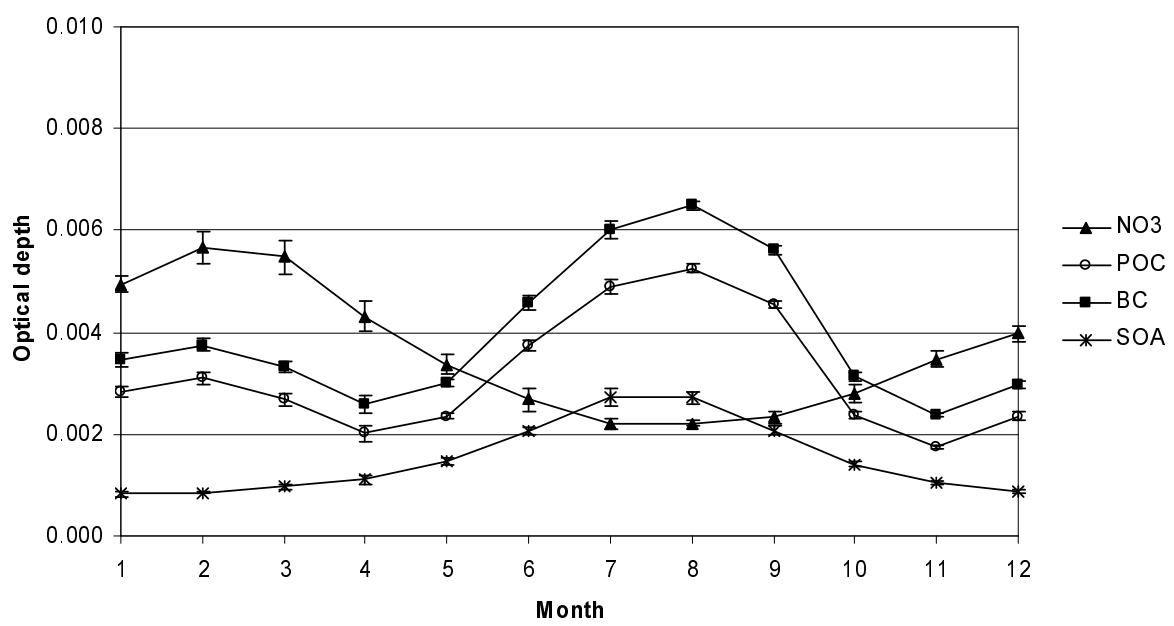

Fig. 10. Monthly mean average OD for the 10-year period of 1984-1993. (a) The error bars show the standard deviation of the interannual results. Total and $\mathrm{SO}_{4}$. (b) OD of other aerosol components.

\section{Conclusions and need for future improvements}

Kanakidou et al. (2000) have shown that the human impact has drastically increased the biogenic SOA chemical production since preindustrial period. This enhanced SOAb chemical production exhibits naturally driven variations that have been studied here. This naturally driven variation in the biogenic SOA production is calculated to equal about $8 \%$ i.e. to be of the same order with the chemical production of SOA from anthropogenic VOC oxidation, whereas the SOA burden issued from biogenic VOC oxidation varies by about $11.5 \%$. Therefore, based on current knowledge, the meteorological factors determining the SOA production cause variability far below the uncertainty of the SOA formation itself (more than a factor of two; Tsigaridis and Kanakidou, 2003).
Meteorological parameters like temperature, water cycle and mixing by transport can affect the temporal and spatial variability of SOA. In particular with regard to the chemical production of SOA from biogenic VOC oxidation, temperature affects the condensation of semi-volatile compounds to the aerosol phase, while the water cycle has a major impact by affecting the removal of aerosols from the atmosphere, the water associated to the aerosol and finally the aerosol optical properties. Atmospheric circulation affects the transport of aerosols, which will change the surfaces available for condensation of the semi-volatile compounds. According to our calculations this feedback mechanism seems to compensate for the effects of temperature and water cycle changes. 
The work presented here has to be viewed as a first attempt to provide insight to the complexity of the climate/biosphere/atmosphere interactions involving SOA. The results largely rely on adopted parameterizations with regard to SOA formation. Improvements are needed to consider also the naturally emitted seasalt and dust particles. These particles could affect the chemical composition of the atmosphere by acting as surfaces for heterogeneous reactions that modify both the gas and aerosol phases. Multiphase chemistry and heterogeneous reactions on particles that produce particulate organic matter have to be considered in future modeling studies when appropriate experimental data will become available. Finally, improved SOA formation parameterizations have to differentiate between high and low $\mathrm{NO}_{x}$ environments and take into account the hygroscopicity of the SOA components.

Acknowledgements. The authors would like to thank F. J. Dentener and M. Krol for their valuable help with the TM3 model and comments. The authors acknowledge support by the EU project PHOENICS (EVK2-CT-2001-00098) and Greek General Secretariat for Research and Technology for PYTHAGORAS II.

Edited by: M. Kulmala

\section{References}

Barsanti, K. C. and Pankow, J. F.: Thermodynamics of the formation of atmospheric organic particulate matter by accretion reactions - part 1: aldehydes and ketones, Atmos. Environ., 38, 4371-4382, 2004.

Bonn, B. and Lawrence, M. G.: Influence of biogenic secondary organic aerosol formation approaches on atmospheric chemistry, J. Atmos. Chem., in press, 2005.

Bonn, B., von Kuhlmann, R., and Lawrence, M. G.: High contribution of biogenic hydroperoxides to secondary organic aerosol formation, Geophys. Res. Lett., 31, L10108, doi:10.1029/2003GL019172, 2004.

Chung, S. H. and Seinfeld, J. H.: Global distribution and climate forcing of carbonaceous aerosols, J. Geophys. Res., 107, 4407, doi:10.1029/2001JD001397, 2002.

Claeys, M., Graham, B., Vas, G., Wang, W., Vermeylen, R., Pashynska, V., Cafmeyer, J., Guyon, P., Andreae, M. O., Artaxo, P., and Maenhaut, W.: Formation of secondary organic aerosols through photooxidation of isoprene, Science, 303, 1173-1176, 2004a.

Claeys, M., Wang, W., Ion, A. C., Kourtchev, I., Gelencsér, A., and Maenhaut, W.: Formation of secondary organic aerosols from isoprene and its gas-phase oxidation products through reaction with hydrogen peroxide, Atmos. Environ., 38, 4093-4098, 2004b.

Cooke, W. F., Liousse, C., Cachier, H., and Feichter, J.: Construction of a $1^{\circ} \times 1^{\circ}$ fossil fuel emission data set for carbonaceous aerosol and implementation and radiative impact in the ECHAM4 model, J. Geophys. Res. 104, 22 137-22 162, 1999.

de Rosnay, P. and Polcher, J.: Modeling root water uptake in a complex land surface scheme coupled to a GCM, Hydrol. Earth Syst. Sci., 2, 239-255, 1998,

SRef-ID: 1607-7938/hess/1998-2-239.
Dentener, F. J., Feichter, J., and Jeuken, A.: Simulation of the transport of $\mathrm{Rn}^{222}$ using on-line and off-line global models at different horizontal resolutions: a detailed comparison with measurements, Tellus 51B, 573-602, 1999.

Derwent, R. G., Collins, W. J., Jenkin, M. E., Johnson, C. E., and Stevenson, D. S.: The global distribution of secondary particulate matter in a 3-D Lagrangian chemistry transport model, J. Atmos. Chem., 44, 57-95, 2003.

Ducoudré, N. I., Laval, K., and Perrier, A.: SECHIBA, a new set of parameterizations of the hydrologic exchanges at the landatmosphere interface within the LMD atmospheric general circulation model, J. Climate 6, 248-273, 1993.

Ervens, B., Feingold, G., Frost, G. J., and Kreidenweis, S. M.: A modelling study of aqueous production of dicarboxylic acids, 1: Chemical pathways and organic mass production, J. Geophys. Res., 109, D15205, doi:10.1029/2003JD004387, 2004.

Falkowski, P., Scholes, R. J., Boyle, E., Canadell, J., Canfield, D., Elser, J., Gruber, N., Hibbard, K., Högberg, P., Linder, S., Mackenzie, F. T., Moore III, B., Pedersen, T., Rosenthal, Y., Seitzinger, S., Smetacek, V., and Steffen, W.: The global carbon cycle: a test of our knowledge of earth as a system, Science, 290, 291-296, 2000.

Ganzeveld, L. and Lelieveld, J.: Dry deposition parameterization in a chemistry general circulation model and its influence on the distribution of reactive trace gases, J. Geophys. Res. 100, $20999-$ $21012,1995$.

Gibson, R., Kallberg, P., and Uppala, S.: The ECMWF re-analysis (ERA) project, ECMWF newsletter, 73, 7-17, 1997.

Griffin R. J., Cocker, D. R. III, Seinfeld, J. H., and Dabdub, D.: Estimate of global atmospheric organic aerosol from oxidation of biogenic hydrocarbons, Geophys. Res. Lett., 26, 2721-2724, 1999.

Guenther, A., Baugh, B., Brasseur, G., Greenberg, J., Harley, P., Klinger, L., Serça, D., and Vierling, L.: Isoprene emission estimates and uncertainties for the Central African EXPRESSO study domain, J. Geophys. Res., 104, 30, 625-30, 639, 1999.

Guenther, A., Geron, C., Pierce, T., Lamb, B., Harley, P., and Fall, R.: Natural emissions of non-methane volatile organic compounds, carbon monoxide, and oxides of nitrogen from North America, Atmos. Environ., 34, 2205-2230, 2000.

Guenther, A., Hewitt, C. N., Erickson, D., Fall, R., Geron, C., Graedel, T., Harley, P., Klinger, L., Lerdau, M., McKay, W. A., Pierce, T., Scholes, B., Steinbrecher, R., Tallamraju, R., Taylor, J., and Zimmerman, P.: A global model of natural volatile organic compound emissions, J. Geophys. Res., 100, 8873-8892, 1995.

Hall, F. G., Collatz, G., Los, S., Brown de Colstoun, E., and Landis, D. (Eds.): ISLSCP Initiative II. NASA. DVD/CD-ROM. NASA, 2004.

Herrmann, H.: Kinetics of Aqueous Phase Reactions Relevant for Atmospheric Chemistry, Chem. Rev., 103, 12, 4691-4716, 2003.

Hoffmann, T., Odum, J. R., Bowman, F., Collins, D., Klockow, D., Flagan, R. C., Seinfeld, J. H.: Formation of organic aerosols from the oxidation of biogenic hydrocarbons, J. Atmos. Chem. 26, 189-222, 1997.

Houweling, S., Dentener, F., Lelieveld, J.: The impact of nonmethane hydrocarbon compounds on tropospheric chemistry, J. Geophys. Res. 103, $10673-10$ 696, 1998. 
Janson, R. and De Serves, C.: Acetone and monoterpene emissions from the boreal forest in northern Europe, Atmos. Environ., 35, 4629-4637, 2001.

Jeuken, A., Veefkind, J. P., Dentener, F., Metzger, S., Gonzalez, C. R.: Simulation of the aerosol optical depth over Europe for August 1997 and a comparison with observations, J. Geophys. Res., 106, 28 295-28 311, 2001.

Kalberer, M., Paulsen, D., Sax, M., Steinbacher, M., Dommen, J., Prevot, A. S. H, Fisseha, R., Weingartner, E., Frankevich, V., Zenobi, R., and Baltensperger, U.: Identification of polymers as major components of atmospheric organic aerosols, Science, 303, 1659-1662, 2004.

Kanakidou, M., Seinfeld, J. H., Pandis, S. N., Barnes, I., Dentener, F. J., Facchini, M. C., van Dingenen, R., Ervens, B., Nenes, A., Nielsen, C. J., Swietlicki, E., Putaud, J. P., Balkanski, Y., Fuzzi, S., Horth, J., Moortgat, G. K., Winterhalter, R., Myhre, C. E. L., Tsigaridis, K., Vignati, E., Stephanou, E. G., and Wilson, J.: Organic aerosol and global climate modelling: a review, Atmos. Chem. Phys., 5, 1053-1123, 2005,

\section{SRef-ID: 1680-7324/acp/2005-5-1053.}

Kanakidou, M., Tsigaridis, K., Dentener, F. J., and Crutzen, P. J.: Human-activity-enhanced formation of organic aerosols by biogenic hydrocarbon oxidation, J. Geophys. Res., 105, 9243-9254, 2000 .

Kesselmeier, J., and Staudt, M.: Biogenic volatile organic compounds (VOC): An overview on emission, physiology, and ecology, J. Atm. Chem., 33, 23-88, 1999.

Kiehl, J. T., and Briegleb, B. P.: The relative roles of sulfate aerosols and greenhouse gases in climate forcing, Science, 260, 311-314, 1993.

Krinner, G., Viovy, N., De Noblet, N., Ogée, J., Polcher, J., Friedlingstein, P., Ciais, P., Sitch, S., and Prentice, I. C.: A dynamic global vegetation model for studies of the coupled atmosphere-biosphere system, Glob. Biogeochem. Cycles, 19, 1, doi:10.1029/2003GB002199, 2005.

Kulmala, M., Suni, T., Lehtinen, K. E. J., Dal Maso, M., Boy, M., Reissell, A., Rannik, Ü., Aalto, P., Keronen, P., Hakola, H., Bäck, J., Hoffmann, T., Vesala, T., and Hari, P.: A new feedback mechanism linking forests, aerosols, and climate, Atmos. Chem. Phys., 4, 557-562, 2004,

SRef-ID: 1680-7324/acp/2004-4-557.

Lack, D. A., Tie, X. X., Bofinger, N. D., Wiegand, A. N., and Madronich, S.: Seasonal variability of secondary organic aerosol: A global modelling study, J. Geophys. Res., 109, D03203 doi:10.1029/2003JD003418, 2004.

Liousse, C., Penner, J. E., Chuang, C., Walton, J. J., Eddleman, H., and Cachier, H.: A global three-dimensional model study of carbonaceous aerosols, J. Geophys. Res., 101, 19411-19432, 1996.

MacDonald, R., and Fall, R.: Detection of substantial emissions of methanol from plants to the atmosphere, Atmos. Environ. 27A, 1709-1713, 1993.

Naik, V., Delire, C., and Wuebbles, D. J.: Sensitivity of biogenic isoprenoid emissions to climate variability and atmospheric $\mathrm{CO}_{2}$, J. Geophys. Res., 109, doi:10.1029/2003JD004236, 2004.
Odum, J. R., Hoffmann, T., Bowman, F., Collins, D., Flagan, R. C., and Seinfeld, J. H.: Gas/particle partitioning and secondary organic aerosol yields, Environ. Sci. Technol. 30, 2580-2585, 1996.

Odum, J. R., Jungkamp, T. P. W., Griffin, R. J., Flagan, R. C., and Seinfeld, J. H.: The atmospheric aerosol-forming potential of whole gasoline vapor, Science, 276, 96-99, 1997.

Olivier, J. G. J., Bouwman, A. F., Van der Maas, C.W. M., Berdowski, J. J. M., Veldt, C., Bloos, J. P. J., Visschedijk, A. J. H., Zandveld, P. Y. J., and Haverlag, J. L.: Description of EDGAR Version 2.0: a set of emission inventories of greenhouse gases and ozone depleting substances for all anthropogenic and most natural sources on a per country basis and on $1^{\circ} \times 1^{\circ}$ grid, RIVM Report no. 771060002 and TNO-MEP Report no. R96/119, 1996.

Pankow, J. F.: An absorption model of gas/particle partitioning of organic compounds in the atmosphere, Atmos. Environ. 28, 185188, 1994a.

Pankow, J. F.: An absorption model of the gas/aerosol partitioning involved in the formation of secondary organic aerosol, Atmos. Environ. 28, 189-193, 1994b.

Parungo, F., Nagamoto, C., Zhou, M.-Y., Hansen, A. D. A., and Harris, J.: Aeolian transport of aerosol black carbon from China to the ocean, Atmos. Environ., 28, 3251-3260, 1994.

Pun, B. K., Wu, S. Y., Seigneur, C., Seinfeld, J. H., Griffin, R. J., and Pandis, S. N.: Uncertainties in modelling secondary organic aerosols: Three-dimensional modelling studies in Nashville/West Tennessee, Environ. Sci. Technol., 37, 36473661, 2003.

Sitch, S., Smith, B., Prentice, I. C., Arneth, A., Bondeau, A., Cramer, W., Kaplan, J. O., Levis, S., Lucht, W., Sykes, M. T., Thonicke, K., and Venevsky, S.: Evaluation of ecosystem dynamics, plant geography and terrestrial carbon cycling in the LPJ dynamic global vegetation model, Glob. Ch. Biol. 9, 161-185, 2003.

Tegen, I., Hollrig, P., Chin, M., Fung, I., Jacob, D., and Penner, J.: Contribution of different aerosol species to the global aerosol extinction optical thickness: Estimates from model results, J. Geophys. Res. 102, 23 895-23 915, 1997.

Tolocka, M. P., Jang, M., Ginter, J., Cox, F., Kamens, R., and Johnston, M.: Formation of oligomers in secondary organic aerosol, Environ. Sci. Technol., 38, 1428-1434, 2004.

Tsigaridis, K. and Kanakidou, M.: Global modelling of secondary organic aerosol in the troposphere: A sensitivity analysis, Atmos. Chem. Phys., 3, 1849-1869, 2003,

SRef-ID: 1680-7324/acp/2003-3-1849.

Veefkind, P.: Aerosol satellite remote sensing. PhD Thesis, Utrecht University, The Netherlands, 1999.

Warneck, P.: In-cloud chemistry opens pathway to the formation of oxalic acid in the marine atmosphere, Atmos. Environ, 37, 24232427, 2003.

Wesely, M. L.: Parameterization of surface resistances to gaseous dry deposition in regional scale numerical models, Atmos. Environ. 23, 1293-1304, 1989. 